\title{
Venous Invasion
}

National Cancer Institute

\section{Source}

National Cancer Institute. Venous Invasion. NCI Thesaurus. Code C47849.

A term referring to the presence of tumor emboli or tumor masses within veins. 